\title{
Resistência bacteriana pelo uso indiscriminado da azitromicina frente a Covid-19:
}

\section{uma revisão integrativa}

\author{
Bacterial resistance to indiscriminate use of azithromycin versus Covid-19: an integrative review
}

Resistencia bacteriana por el uso indiscriminado de azitromicina versus Covid-19: una revisión

integradora

Recebido: 21/12/2021 | Revisado: 28/12/2021 | Aceito: 04/01/2022 | Publicado: 07/01/2022

\author{
Marinete Sousa Freires \\ ORCID: https://orcid.org/0000-0002-6220-6958 \\ Universidade Nilton Lins, Brasil \\ E-mail: mary_sousa_2008@hotmail.com \\ Omero Martins Rodrigues Junior \\ ORCID: https://orcid.org/0000-0002-8552-3278 \\ Universidade Nilton Lins, Brasil \\ E-mail: omeromartins.farma@gmail.com
}

\begin{abstract}
Resumo
Recentemente uma doença causada por um novo corona vírus, o sars-cov2, foi descrita como Covid-19, e se espalhou obtendo o caráter pandêmico, espalhou-se a disseminação viral e consequente elevação no número de mortes em todo o mundo, houve uma crescente ascensão na divulgação de notícias origem profilática, notou-se um crescimento na curva de automedicação por indivíduos, em grande parte, influenciados por notícias falsas disponibilizadas em mídias sociais e em debates sem embasamento científico. Neste sentido, um fármaco que se evidencia é a Azitromicina, um antibiótico do tipo azalida, que foi amplamente prescrita e utilizada em larga escala pela população em geral. Ao utilizar a Azitromicina pelo seu efeito imunomodulador dentro de uma patologia que é essencialmente viral, abre-se as portas para o aumento da resistência bacteriana à essa medicação e sua classe medicamentosa. Há plausibilidade para afirmar que o uso indiscriminado desse antibiótico, independentemente de sua função buscada, aumenta a possibilidade de seleção de bactérias resistentes. Objetivo: Para tanto, objetivou-se descrever a resistência bacteriana pelo uso indiscriminado da Azitromicina frente a Covid-19. Material e Método: Tratou-se de uma revisão integrativa de literatura junto às bases de dados LILACS, PUBMED/MEDELINE e SCIELO, entre 2019 e 2021. Identificaram-se 75 artigos, sendo 10 utilizados na elaboração do trabalho. Resultados mostram que a automedicação durante este período pandêmico, enfatizando o uso indiscriminado da azitromicina, além de ressaltar os fatores que contribuem para tal prática que corroboram para o aumento da resistência bacteriana. Fatores como erros nas indicações médicas, automedicação por parte da população e uma fiscalização ineficaz na venda dos antimicrobianos, em farmácias e drogarias, onde se concentram estes medicamentos, colaboram para a multirresistência bacteriana. Conclusão: É necessário orientar e esclarecer, tanto profissionais da saúde como a população, sobre a resistência bacteriana, assim como a indicação e utilização correta e eficaz dos antibióticos contra as doenças infecciosas.
\end{abstract}

Palavras-chave: Resistência bacteriana; Antimicrobianos; Covid-19; Azitromicina.

\begin{abstract}
Recently a disease caused by a new corona virus, sars-cov2, was described as Covid-19, and it spread, getting a pandemic character, viral spread and consequent increase in the number of deaths worldwide, there was a Growing rise in the dissemination of prophylactic news, there was an increase in the curve of self-medication by individuals, in large part, influenced by false news made available on social media and in debates without scientific basis. In this sense, a drug that stands out is Azithromycin, an antibiotic of the azalide type, which was widely prescribed and used on a large scale by the general population. By using Azithromycin, due to its immunomodulating effect in a pathology that is essentially viral, it opens the door to an increase in bacterial resistance to this medication and its drug class. It is plausible to say that the indiscriminate use of this antibiotic, regardless of its intended function, increases the possibility of selecting resistant bacteria. Objective: Therefore, the objective was to describe bacterial resistance due to the indiscriminate use of Azithromycin compared to Covid-19. Material and Method: This was an integrative literature review from the LILACS, PUBMED/MEDELINE and SCIELO databases, between 2019 and 2021.75 articles were identified, 10 of which were used in the preparation of the work. Results show that self-medication during this pandemic period, emphasizing the indiscriminate use of Azithromycin, in addition to emphasizing the factors that contribute to this practice, which contribute to the increase in bacterial resistance. Factors such as errors in medical indications, selfmedication by the population and an ineffective inspection of the sale of antimicrobials, in pharmacies and drugstores, where these drugs are concentrated, contribute to bacterial multi-resistance. Conclusion: It is necessary to guide and
\end{abstract}


clarify, both health professionals and the population, about bacterial resistance, as well as the correct and effective indication and use of antibiotics against infectious diseases.

Keywords: Bacterial resistance; Antimicrobials; Covid-19; Azithromycin.

\begin{abstract}
Resumen
Recientemente, una enfermedad provocada por un nuevo virus corona, el sars-cov2, fue descrita como Covid-19, y se ha extendido, adquiriendo carácter pandémico, diseminación viral y consecuente aumento en el número de muertes a nivel mundial, se ha producido un incremento creciente. en difusión. de las noticias profilácticas, hubo un aumento en la curva de automedicación por parte de los individuos, influenciado en gran medida por las noticias falsas difundidas en las redes sociales y en los debates sin base científica. En este sentido, un medicamento que se destaca es la azitromicina, un antibiótico de tipo azalida, ampliamente prescrito y utilizado a gran escala por la población en general. El uso de azitromicina, por su efecto inmunomodulador en una patología esencialmente viral, abre la puerta a un aumento de la resistencia bacteriana a este fármaco y su clase de fármacos. Es plausible decir que el uso indiscriminado de este antibiótico, independientemente de su función prevista, aumenta la posibilidad de seleccionar bacterias resistentes. Objetivo: Por tanto, el objetivo fue describir la resistencia bacteriana por el uso indiscriminado de azitromicina contra Covid-19. Material y Método: Se realizó una revisión integradora de la literatura en las bases de datos LILACS, PUBMED / MEDELINE y SCIELO entre 2019 y 2021. Se identificaron 75 artículos, 10 de los cuales se utilizaron en la elaboración del trabajo. Los resultados muestran la automedicación en este período pandémico, destacando el uso indiscriminado de azitromicina, además de destacar los factores que contribuyen a esta práctica, que contribuyen al aumento de la resistencia bacteriana. Factores como los errores en las indicaciones médicas, la automedicación de la población y la inspección ineficaz de la venta de antimicrobianos, en farmacias y droguerías, donde se concentran estos fármacos, contribuyen a la multirresistencia bacteriana. Conclusión: Es necesario orientar y esclarecer, tanto a los profesionales de la salud como a la población, sobre la resistencia bacteriana, así como la correcta y eficaz indicación y uso de antibióticos frente a enfermedades infecciosas.
\end{abstract}

Palabras clave: Resistencia bacteriana; Antimicrobianos; Covid-19; Azitromicina.

\title{
1. Introdução
}

Os antibióticos são fármacos que revolucionaram o tratamento de doenças infecciosas causadas por bactérias e reduziram mundialmente as taxas de morbidade e mortalidade associadas a infecções bacterianas. Entretanto, o mau uso desses fármacos acelera o processo natural de resistência das bactérias contra os antibióticos, devido ao fato de que no ambiente natural esses antimicrobianos são produzidos por populações microbianas como ferramenta de competição por recursos nutricionais e espaço dentro do micro-habitat que ocupam. Sendo preocupante a forma como esses medicamentos são utilizados em ambientes ambulatoriais, hospitalares e domésticos no tratamento ou profilaxia de doenças humanas (Costa,2016). A resistência aos antibióticos se desenvolve como uma natural consequência da habilidade da população bacteriana de se adaptar, o uso indiscriminado de antibióticos aumenta a pressão seletiva e também a oportunidade da bactéria ser exposta aos mesmos, aquela oportunidade facilita a aquisição de mecanismos de resistência (Meireles, 2008).

A resistência aos antimicrobianos pode ser: 1) uma característica intrínseca de certas espécies de bactérias que podem resistir à ação de um dado antibiótico como resultado de uma característica estrutural ou funcional inerente de dada espécie (Blair et al., 2015); 2) ser adquirida como resultado de mutações que podem ocorrer durante a replicação celular ou serem induzidas por intermédio de agentes mutagênicos como radiações ionizantes e não ionizantes, agentes alquilantes ou espécies reativas de oxigênio (ROS) (Baptista, 2013); 3) adquirida pela aquisição de material genético exógeno anteriormente presente em outros micro-organismo que contenham genes de resistência que são propagados por meio de mecanismos de transferência gênica horizontal ( Costa, 2016).

Em dezembro de 2019 após um surto de pneumonia desconhecida em Wuhan, na China (Uzunian \& Wanh,2020), uma infecção oriunda da presença do novo Corona vírus, SARS-CoV-2, um RNA-vírus zoonótico, de fita simples,se espalhou desde a sua origem por muitos países ao redor do mundo, provocando altos índices de morbimortalidade em escala mundial. Com a emergência internacional, posteriormente foi declarada a pandemia do Covid-19. Diante da grande repercussão sobre a atual pandemia, vem se observando o comportamento de indivíduos em automedicar-se, fazendo o uso indiscriminado dos antibióticos

(Sharma et al., 2020). 
É válido ressaltar que a terapia antimicrobiana está sendo aplicada não só pela comunidade médica, no ambiente hospitalar, mesmo sem o embasamento científico de sua eficácia no tratamento da Covid-19, mas também pela população leiga que faz uso da automedicação, que é amplamente estimulada pelas Fake News, notícias falsas que circulam pela mídia e redes sociais de forma geral, e pelas indicações de diversos profissionais, sejam eles da área da saúde ou não (Guimarães et al.,2020).

As infecções por corona vírus por SARS provocam inflamação e subsequente dano tecidual nos pulmões em casos moderados a graves o uso de drogas imunomoduladoras como o antibacteriano azitromicina (AZM) poderia proporcionar um benefício no tratamento de Covid-19 (Ye et al., 2020).

Wong (2020) complementa que no atual cenário da pandemia causada pelo Covid-19, a automedicação se tornou um risco potencial, dando exemplo da utilização da azitromicina, que em sobre dosagem ou em indivíduos que são susceptíveis, podem causar alterações hepáticas e renais.

A azitromicina é o primeiro antibiótico de uma nova classe de substâncias denominadas "azalídeos" um antibiótico muito utilizado no combate á infecções bacterianas, e faz parte da família dos macrolídeos apresentando ainda atividade antiviral e imunomoduladora. Existem muitas vias que suportam o potencial mecanismo de atuação da atividade imunomoduladora da azitromicina, que se dá através da supressão da ativação das células linfócito T helper CD4+ (Th CD4+), redução da produção de citocinas próinflamatórias (interleucina IL-1 $\beta$, interleucina IL-6, interleucina IL-8, interleucina IL-12, interferon gamaIFN$\gamma$,fator de necrose tumoral alfaTNF- $\alpha$, fator estimulador de colônia de granulócitos-macrófagosGM-CSF), além da mudança na polarização para fenótipo anti-inflamatório e aumento do apoptose em macrófagos alveolares(Calderón et al.,2018).

Quanto a atividade antiviral, neste contexto pandêmico, seus mecanismos de ação incluem a ligação da droga ao local de ligação ao gangliosídeo, disposto na proteína Spike do SARS-COV2, além de interferir no receptor cluster de diferenciação 147 (CD147) do ligante, e outro mecanismo antiviral ocorre através de um aumento no potencial hidrogeniônico (pH)lisossomal, provocando um prejuízo na atividade das catepsinasclivadoras da proteína S, prejudicando o processo de endocitose (Neto,2020).

Analisando esta abordagem, pode-se compreender que o uso indiscriminado de antibióticos é considerado o principal fator para o desenvolvimento da resistência bacteriana, muitas vezes ocasionado pela falta de conhecimento de quem faz o uso ou pela dificuldade de acesso aos serviços de saúde, o que leva o indivíduo a automedicação (Vieira,2017). Segundo Saldanha et al. (2018) o aumento da resistência bacteriana causa grandes impactos, principalmente em áreas hospitalares, uma vez que aumentam o número de morbimortalidades, sendo assim, a educação populacional sobre o consumo consciente de antibióticos é de suma importância para combater esse problema. Diante deste esclarecimento, objetivamos com este trabalho, realizar um estudo de revisão sobre a resistência à azitromicina promovida pela utilização indiscriminada de antibióticos durante a pandemia do Covid-19.

\section{Metodologia}

Este é um estudo de revisão integrativa, desenvolvida através de uma abordagem qualitativa com o tipo de pesquisa descritiva, onde o objetivo deste tipo de estudo é sintetizar o conteúdo de vários materiais e analisar criticamente as informações obtidas (Pereira et al., 2018). Três plataformas digitais foram utilizadas para a coleta de dados: Medical Literature Analysis and Retrieval System Online - MEDLINE/PUBMED, Literatura Latino-Americana e do Caribe em Ciências da Saúde - LILACS e Scientific Electronic Library Online - SciELO, com base em estudos publicados entre 2019 e 2021.

Foram adotados os seguintes critérios de exclusão: trabalhos que não corresponderam ao objetivo da pesquisa, não estavam disponibilizados na integra ou que estavam fora do período temporal demarcado. Os critérios de inclusão: caracterizamos artigos originais, completo e gratuito que tivessem foco no estudo de Resistência bacteriana pelo uso indiscriminado, da Azitromicina frente a Covid-19, publicados nos idiomas inglês e português. 
A pesquisa foi realizada no intervalo de tempo de outubro a dezembro de 2021, com os seguintes descritores como fonte: "Resistência bacteriana a antibióticos" Resistência a azitromicina" e "Pandemia Covid-19". Os seguintes descritores foram usados na base de dados MEDLINE/PUBMED, e resultaram em 20 artigos, 3 dos quais preencheram os critérios de inclusão. $\mathrm{Na}$ base de dados LILACS, 10 artigos foram selecionados por título e leitura abstrata, sendo que apenas 2 se enquadraram nos critérios de inclusão. No SCIELO, 45 artigos foram selecionados por título e leitura de resumo, 5 dos quais preenchiam os critérios de seleção de acordo com o organograma da metodologia (Figura 1), ao final obteve-se 10 artigos para compor a revisão integrativa.

Em seguida, os resultados dos estudos foram sintetizados, procurando cobrir sua relevância. Os dados dos estudos foram reunidos e sistematizados, caracterizando a análise crítica com o objetivo de gerar novos entendimentos sobre a resistência bacteriana pelo uso indiscriminado da azitromicina frente a Covid-19.

Figura 1 - Ilustração representativa do processo metodológico da revisão integrativa da literatura.
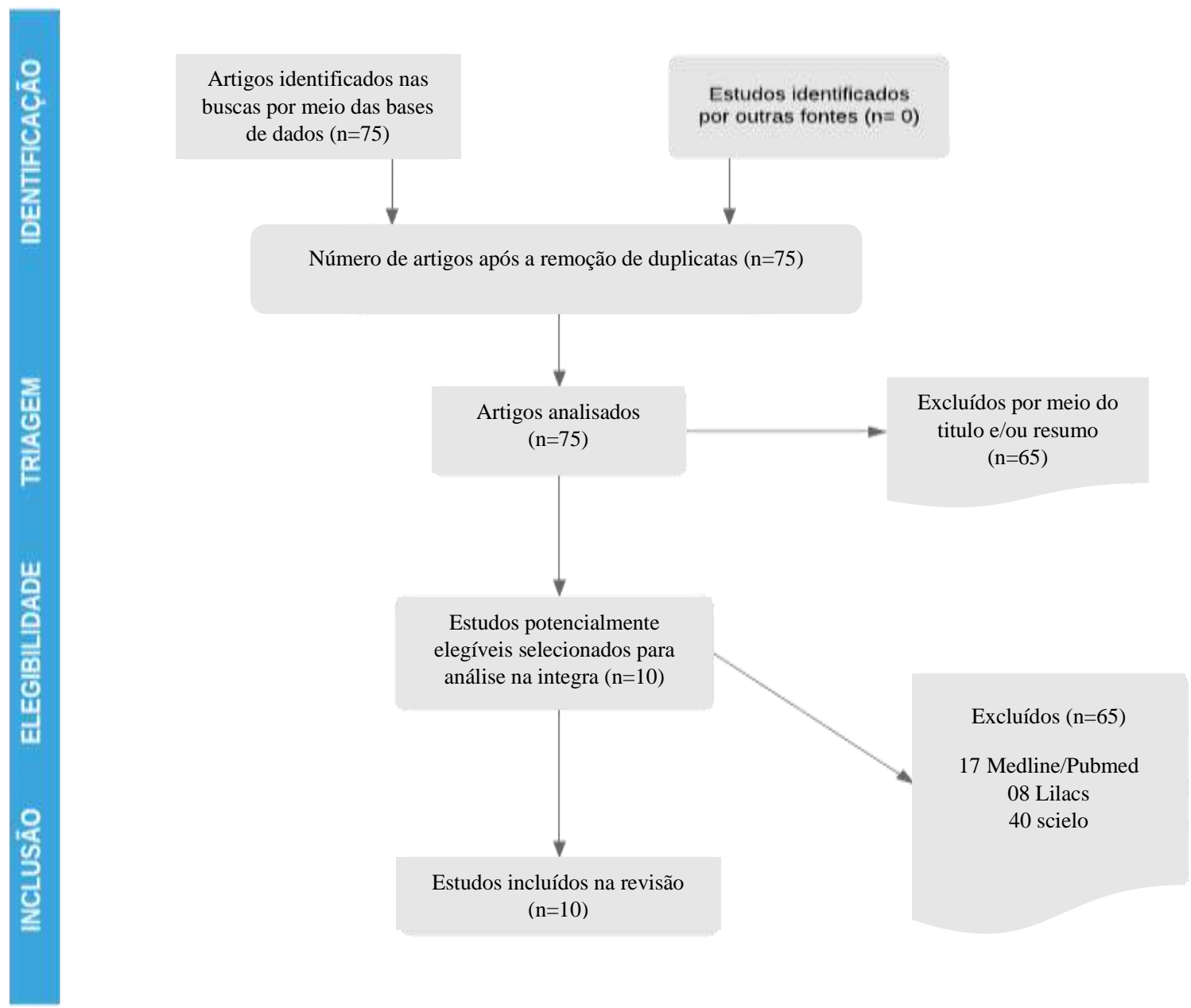

Fonte: Autores (2021).

\section{Resultados e discussão}

Diante dos resultados encontrados após os critérios de exclusão e inclusão, desenvolveu-se um quadro com as características dos principais artigos selecionados, como descrito a seguir no Quadro 1: 
Quadro 1. Características dos artigos analisados.

\begin{tabular}{|c|c|c|c|}
\hline $\begin{array}{l}\text { AUTOR, } \\
\text { ANO }\end{array}$ & TÍTULO & OBJETIVOS & PRINCIPAIS RESULTADOS \\
\hline $\begin{array}{l}\text { Acevedo., et } \\
\text { al } 2020 \\
\text { Blair,2015 }\end{array}$ & $\begin{array}{l}\text { Resistência bacteriana aos } \\
\text { antibióticos e Saúde Pública: } \\
\text { uma breve revisão de literatura }\end{array}$ & $\begin{array}{l}\text { Limitações que a resistência } \\
\text { bacteriana impõe à } \\
\text { utilização destes fármacos } \\
\text { em diferentes âmbitos }\end{array}$ & $\begin{array}{l}\text { mecanismos bioquímicos e genéticos da resistência } \\
\text { bacteriana, assim como os fatores econômicos, sociais, } \\
\text { propedêuticos, terapêuticos e epidemiológicos } \\
\text { associados ao aparecimento de patógenos resistentes. }\end{array}$ \\
\hline $\begin{array}{l}\text { Bosseboeuf } \\
\text { E,2018 }\end{array}$ & $\begin{array}{l}\text { Efetividade e toxicidade da } \\
\text { cloroquina da } \\
\text { hidroxicloroquina associada } \\
\text { (ou não) à azitromicina para } \\
\text { tratamento da Covid-19. O que } \\
\text { sabemos até o momento? }\end{array}$ & $\begin{array}{l}\text { identificar as evidências } \\
\text { científicas sobre a } \\
\text { efetividade do uso da } \\
\text { cloroquina, } \\
\text { hidroxicloroquina associada } \\
\text { (ou não) à azitromicina }\end{array}$ & $\begin{array}{l}\text { Dos sete ensaios clínicos analisados, cinco apresentaram } \\
\text { resultados de cura e/ou remissão dos sintomas e/ou } \\
\text { redução da carga viral dos pacientes, no entanto } \\
\text { apresentaram muitas limitações }\end{array}$ \\
\hline $\begin{array}{l}\text { Gautret } \\
2020\end{array}$ & $\begin{array}{l}\text { Resistência Bacteriana aos } \\
\text { Macrolídeos: Um olhar sobre } \\
\text { a Azitromicina. }\end{array}$ & $\begin{array}{lr}\begin{array}{l}\text { Avaliar o } \\
\text { indiscriminado }\end{array} \\
\text { azitromicina. }\end{array}$ & $\begin{array}{l}\mathrm{O} \text { uso indiscriminado desse antibiótico, } \\
\text { independentemente de sua função buscada, aumenta a } \\
\text { possibilidade de seleção de bactérias resistentes. }\end{array}$ \\
\hline $\begin{array}{l}\text { Marquioti,201 } \\
5\end{array}$ & $\begin{array}{lcr}\text { Mecanismo de resistência } \\
\text { bacteriana frente aos } \\
\text { fármacos: uma revisão. }\end{array}$ & $\begin{array}{l}\text { Analisar mecanismos } \mathrm{de} \\
\text { defesa bacteriana } \mathrm{e}, \\
\text { consequentemente, } \\
\text { resistência adquirida com o } \\
\text { uso indiscriminado dos } \\
\text { antibióticos }\end{array}$ & $\begin{array}{l}\text { É necessário orientar e esclarecer, tanto profi ssionais da } \\
\text { saúde como a população, sobre a resistência bacteriana, } \\
\text { assim como a indicação e utilização correta e efi caz dos } \\
\text { antibióticos contra as doenças infecciosas. }\end{array}$ \\
\hline Wang,2020 & $\begin{array}{l}\text { O uso de antimicrobiano na } \\
\text { Covid- } 19 \text { e as infecções: o que } \\
\text { sabemos. }\end{array}$ & $\begin{array}{l}\text { discutir pontos importantes } \\
\text { dedicados ao manejo de } \\
\text { pacientes com Covid-19 em } \\
\text { uso de antibióticos. }\end{array}$ & $\begin{array}{l}\text { A seleção da terapia antimicrobiana empírica para co- } \\
\text { infecção respiratória bacteriana e as recomendações para } \\
\text { a duração do tratamento requerem várias considerações. }\end{array}$ \\
\hline $\begin{array}{l}\text { Sharma } \\
\text { al.,2020 }\end{array}$ & $\begin{array}{l}\text { Análise da Automedicação } \\
\text { Durante a Pandemia do novo } \\
\text { Coronavírus: um olhar sobre a } \\
\text { azitromicina }\end{array}$ & $\begin{array}{l}\text { Debater sobre o aumento da } \\
\text { automedicação durante este } \\
\text { período pandêmico uso } \\
\text { indiscriminado ra } \\
\text { Azitromicina. }\end{array}$ & $\begin{array}{l}\text { A automedicação traz consigo diversos perigos, entre } \\
\text { eles os efeitos colaterais ocasionados pela interação } \\
\text { medicamentosa ou alimentar, o que eleva o número de } \\
\text { comorbidades e mortalidades em tempos de pandemia, } \\
\text { além de exercer uma pressão negativa sobre os } \\
\text { microrganismos. }\end{array}$ \\
\hline $\begin{array}{l}\text { Principi } \\
\text { N,2020 }\end{array}$ & $\begin{array}{l}\text { Cloroquina } r \\
\text { hidroxicloroquina associado } \\
\text { ao zinco e/ou azitromicina na } \\
\text { Covid-19 }\end{array}$ & $\begin{array}{l}\text { Mostrar os usos da CQ e } \\
\text { HCQ, os mecanismos } \\
\text { propostos como anti-Covid- } \\
19 \text { isoladamente ou em } \\
\text { associação } \\
\text { azitromicina. }\end{array}$ & $\begin{array}{l}\text { resultados apresentados até o momento, se mostram } \\
\text { duvidosos e insuficientes para corroborar o uso da CQ } \\
\text { da HCQ como tratamento de primeira escolha para casos } \\
\text { de Covid-19, devido a sua curta janela de segurança e } \\
\text { alta toxicidade. }\end{array}$ \\
\hline $\begin{array}{l}\text { Michael.P,et } \\
\text { al ,2014 }\end{array}$ & $\begin{array}{l}\text { Azitromicina: Mecanismos de } \\
\text { ação e sua relevância para } \\
\text { aplicações clínicas }\end{array}$ & $\begin{array}{l}\text { Analisar mecanismo de ação } \\
\text { da Azitromicina. }\end{array}$ & $\begin{array}{l}\text { A modulação das respostas do hospedeiro facilita seu } \\
\text { benefício terapêutico de longo prazo. }\end{array}$ \\
\hline
\end{tabular}

Fonte: Autores (2021).

\subsection{Azitromicina}

A azitromicina é um antibiótico do tipo azalida e proveniente da eritromicina. Contém uma substituição de um grupo carbonil por um grupo metil, formando assim o anel lactona com 15 carbonos, 12 que pertence ao grupo dos macrolídeos, grupo conhecido desde a década de 50 e com vários integrantes frequentemente utilizados na prática clínica. Estes agentes bacteriostáticos atuam se ligando a trechos específicos do RNA ribossomal bacteriano, interferindo no processo de elongação da cadeia peptídica durante a translação e embargando o processo antes que a síntese proteica seja concluída pela bactéria (Adam et al.,2021).

Segundo Pani et al., (2020) além de bacteriostático, a azitromicina também pode atuar de forma bactericida a depender de algumas características, dentre elas as concentrações plasmáticas e teciduais.

De acordo com Gautret(2020) Dentro da longa lista de tentativas de enfrentamento do SARS-COV-2, um dos medicamentos mais largamente prescritos foi a Azitromicina, sua utilização se baseia na tentativa de inibir a replicação viral e atuar como imunomodulador, diminuindo a gravidade dos casos da Covid-19. 
Estudos recentes de Bosseboeufe (2018) demonstraram que alguns antibióticos e agentes antiparasitários podem inibir a replicação viral. A azitromicina teve ação antiviral comprovada contra o zika vírus in vitro e reduziu sua proliferação em células da glia, componentes do sistema neurológico.

A utilização inadequada da azitromicina pode causar um aumento significativo na taxa de resistência bacteriana, atingindo grandes dimensões no contexto da pandemia (Oliveira,2016). Segundo Júnior (2019) os antibióticos reduzem a taxa de mobimortalidade por infecções bacterianas em escala global, mas que com o passar do tempo, o aumento de casos de resistência bacteriana aos antimicrobianos tem se elevado, tornando necessárias elaborações de medidas preventivas, visando à melhoria e minimização dos efeitos da resistência bacteriana, assim como evitar novas cepas multirresistentes.

\subsection{Mecanismo de Ação da Azitromicina}

O mecanismo de ação da azitromicina sucede por meio da inibição que ocorre na síntese proteica de RNA, mediante uma ligação nos receptores encontrados na porção 50S do ribossomo, principalmente na molécula da porção 23S do RNA, resultando em um impedimento nas reações de translocação e transpeptidação, e assim, atuam em bactérias gram positivas e gram negativas tendo emprego contra infecções principalmente respiratórias com características pneumônicas ou do trato superior (Acevedo et al., 2020). Já o mecanismo de resistência pode surgir devido ao decrescimento que acontece na permeabilidade da própria célula ao antimicrobiano, ou por meio de alterações no sítio receptor da porção 50S até chegar na inativação enzimática (Almeida,2010).

Este bloqueio dificulta que o peptidil-RNArdê sequência na fase de translocação da cadeia peptídica e impede a liberação do sítio ribossômico e sua inserção da amina no anel macro cíclico, proporcionando a molécula uma melhor ação em meio ácido e possibilitando um alto índice de concentração tecidual, diminuindo os efeitos adversos da classe (Iriarte,2020).

A Azitromicina se destaca dos outros integrantes do grupo não pelo seu mecanismo de ação, que é semelhante aos outros da classe, mas pela sua capacidade em atuar em novos microrganismos. A inclusão do grupo amina no anel macrocíclico, que fornece a molécula maior potencial básico, possibilitou a essa droga melhor atuação em meio ácido, além de também ter diminuído os efeitos adversos da classe. Essa mudança permite que a molécula atravesse mais rapidamente e de maneira mais eficaz a membrana externa das bactérias, um mecanismo de proteção importante das bactérias Gram-negativas (Davidson,2019; Michael,2014).

Ao analisar análogos químicos da azitromicina por simulação de computador, Braz (2020) observou que ela pode interagir com enzimas de trabalho. Na replicação molecular do SARS-CoV2.Fantini; Chahinian e Yahi (2020) propuseram que o efeito antiviral da azitromicina se deve à sua interação com a proteína spike do coronavírus para evitar que o vírus entre na célula hospedeira. Na pesquisa realizada por Ulrich; Pillow; Micheli (2020) propõe que o mecanismo de ação inclui a regulação da interação do vírus com o receptor CD147 Além de aumentar os níveis de interferon inibindo a replicação, nas células hospedeiras Viral.

Para Coleson et al. (2020), seu efeito de ajuste de pH endossomal parece ser responsável pelos efeitos do novo corona vírus no tratamento, este mecanismo em testes in vitro contra o vírus Zika e o vírus Ebola.

Para Bosseboeuf et al. (2018) e Gautret et al., 2020 Azitromicina mostra atividade Devido à inativação de Rho, medicamentos antivirais para zika vírus em estudos in vitro Quinase de células epiteliais das vias aéreas humanas.

\subsection{Farmacocinética}

Azitromicina tem um grande potencial e uma excelente farmacocinética, com concentração tecidual cerca de 100 vezes maior do que no plasma e 200 vezes maior no espaço intracelular do que no espaço extracelular. Como há grande concentração em fagócitos e polimorfonucleares, há entrega adequada aos locais de infecção, sendo liberado no espaço extracelular pela lise 
celular causada pelas bactérias. Tem metabolização muito pequena e não deixa metabólitos ativos circulantes. Ao contrário do que se cogitava inicialmente, a baixa concentração plasmática da droga não se deve à alta excreção ou baixa 11 biodisponibilidade, mas sim à alta distribuição para os tecidos (Rang,2010; Fuchs,2010).

$\mathrm{Na}$ absorção por via oral, a azitromicina é distribuída pelo corpo e aproximadamente $37 \%$ está presente na etapa de biodisponibilidade, sua distribuição acontece de acordo com o tempo de alcançar a maior concentração plasmática, normalmente entre duas a três horas, sua meia-vida plasmática é de dois a quatro dias. Sabe-se que biotransformação do fármaco se encontra maior nos tecidos com a presença de altas concentrações no interior das células e em sua eliminação o fármaco sofre o metabolismo hepático em metabolitos inativos, sendo excretado em sua forma inalterada pela urina (Berson,2020).

\subsection{Mecanismo de aquisição da resistência bacteriana}

Ao longo do tempo, as bactérias desenvolveram vários mecanismos de defesa, apresentando algumas estirpes extremamente resistentes aos antibióticos. Esta resistência pode ocorrer com: a exposição às drogas, através da mutação genética; pelos plasmídeos, que são pequenos fragmentos de DNA que levam a resistência de uma bactéria para outra; através de recombinação gênica pela conjugação, transformação, transdução ou transposição. Existem ainda mecanismos de defesa presentes na célula bacteriana como as porinas e as bombas de efluxo (Moreno 2017).

O uso frequente de antibióticos de amplo espectro para Covid-19 pretendidos para eliminar uma ampla gama de bactérias podem estimular a resistência antimicrobiana (RAM) através do uso excessivo. Tais achados dão suporte às preocupações dos pesquisadores de que o aumento do uso de antibióticos durante a pandemia poderia aumentar a ameaça a longo prazo da RAM (Hsu. 2020).

Pesquisa apoiada por dados de Wuhan mostra que o número de pacientes recebendo tratamento com antibióticos varia de $71 \%$ a $95 \%$, e o problema de bactérias altamente resistentes é complicado de lidar (Zho et al., 2020; Chen et al., 2020). Obviamente, a coinfecção com bactérias resistentes a antibióticos (superbactérias) levará a uma maior mortalidade em casos de Covid-19 (Lupia, et al.,2019).

Em geral, está claro que o tratamento inadequado de Covid-19 e infecções secundárias e o uso de antibióticos como medidas preventivas podem ser os principais fatores de resistência antimicrobiana (RAM). Como um ex-diretor dos Centros de Controle e Prevenção de Doenças (CDC) apontou: “À medida que o número de pneumonias causadas pelo coronavírus aumenta e o número de unidades de terapia intensiva aumenta, o desafio da resistência aos antibióticos pode se tornar um desafio para todo o sistema de saúde. O imenso poder de doenças e mortes adicionais está além de suas capacidades (Gerberding, (2020).

Segundo Opal S.M(2015) os mecanismos de resistência bacterianos contra os macrolídeos, incluindo a Azitromicina, podem atuar diretamente na ação direta contra síntese proteica, na inativação da molécula ou ao dificultar o acesso do antibiótico ao sítio efetor.

Griffith (2019) aponta que principal ação das bactérias contra os macrolídeos é a alteração do alvo desse tipo de efeito no ribossomo. As bactérias usam o gene erm para desmetilar o nucleotídeo de adenina da subunidade 23S, alterar sua conformação 12 , impedir que o macrolídeo se ligue ao ribossomo e interromper a translocação da cadeia peptídica.

Outras alterações que aumentam a resistência aos macrolídeos são as bombas de efluxo, as alterações na permeabilidade da membrana e a inativação enzimática (que não afeta o mecanismo da azitromicina). Os estafilococos e estreptococos produzem proteínas responsáveis pelo escoamento dos macrolídeos para fora do citoplasma, reduzindo a concentração efetiva dos antibióticos na célula, evitando assim seus efeitos efetivos. As bactérias Gram-negativas podem ter diferentes proteínas de poro em suas membranas celulares, impedindo a azitromicina de entrar no espaço citoplasmático, que é um mecanismo menos comum. Esses mecanismos de resistência podem envolver os plasmídeos, estruturas 
extracromossomais, com moléculas de DNA independentes do cromossomo bacteriano que não carregam informações genéticas essenciais à homeostasia bacteriana, mas que podem conferir vantagens evolutivas. (Opal 2015).

Ainda há pouca informação sobre como a pandemia afeta diretamente os níveis gerais de RAM, mas uma revisão dos dados sobre os casos de Covid-19, principalmente na Ásia, constatou que, embora menos de 10\% em média, mais de $70 \%$ dos pacientes receberam terapia antimicrobiana. Coinfecção bacteriana ou fúngica (Rawson et al., 2020).

Percebe-se que entre os pacientes com Covid-19, a proporção geral de coinfecção bacteriana esta sendo baixa porém, o uso de antibióticos é alto, sendo assim não existe evidências suficientes para apoiar o uso disseminado de antibióticos empíricos em pacientes hospitalizados por Covid-19 com o risco de com o uso excessivo de antibióticos e danos subsequentes associados à resistência bacteriana.

\section{Considerações Finais}

Dada a plausabilidade bioquímica, farmacológica e evolutiva dos processos que envolvem a criação de novos mecanismos de resistência ou então da sua concentração e seleção apresentadas neste texto, é possível afirmar que o uso irracional de antibióticos, seja por espectro além do necessário ou por indicações indevidas, eleva a prevalência de microrganismos resistentes aos medicamentos.

Ao longo do tempo, as bactérias desenvolveram vários mecanismos de defesa, apresentando algumas estirpes extremamente resistentes aos antibióticos. Esta resistência pode ocorrer com: a exposição às drogas, através da mutação genética; pelos plasmídios, que são pequenos fragmentos de DNA que levam a resistência de uma bactéria para outra; através de recombinação gênica pela conjugação, transformação, transdução ou transposição. Existem ainda mecanismos de defesa presentes na célula bacteriana como as porinas e as bombas de efluxo. Vários profissionais da saúde como médicos, farmacêuticos, enfermeiros e até mesmo a população, estão envolvidos no controle e uso dos antibióticos. A indicação correta, a dispensação fiscalizada, os cuidados padronizados e supervisionados pelos CCIHs nos hospitais, são essenciais para o controle da resistência bacteriana frente aos fármacos. Assim, o conhecimento sobre a resistência bacteriana e seus mecanismos de defesa se faz necessário para adquirir métodos eficazes de prevenção e tratamento contra as infecções multirresistentes

Por conseguinte, sugere-se, medidas para evitar a resistência bacteriana, campanhas que venham abordar sobre o tema e que possam conscientizar sobre o uso indiscriminado de medicamentos, como o uso racional dos antibióticos, prevenção de infecções bacterianas, controle e prevenção da disseminação de micro-organismos resistentes são essenciais, assim como a busca por novos metabólitos ativos contra diferentes micro-organismos patogênicos devem ser ativas, contínuas (Guimarães et al., 2010).

Sugere-se mais estudos sobre a resistência bacteriana, campanhas que venham abordar sobre o tema e que possam conscientizar sobre o uso indiscriminado de medicamentos que levam a desenvolver bactérias multirresistência e mostrar a importância do uso racional de medicamentos.

\section{Referências}

Almeida, F. B., Cabral, S. A. A. O., Alencar, M. C. B., Figueiredo, C. H. A., Silveira, D. C., \& Farias, W. K. A. (2010). Atenção farmacêutica em análises da dispensação de antimicrobianos em farmácia. Revista Brasileira de Educação e Saúde. 5(4),23-29. doi.org/10.51891/rease. v7i8.1984.

Adam, A. M. A., Saad, H. A., Alsuhaibani, A. M., Refat, M. S., \& Hegab, M. S. (2021). Química de transferência de carga da azitromicina, o antibiótico usado mundialmente para tratar a doença do coronavírus (Covid-19). Parte III: Um protocolo verde para síntese fácil de complexos com aceitadores TCNQ, DDQ e TFQ., Jornal de moléculas líquidas, Elsevier.355(1), 1-12.

Berson, L. R. S. (2020). ZitromaxIV azitromicinadi-hidratada. Wyeth Indústria Farmacêutica Ltda.7(80)1-5 21. doi.org/10.51891/rease. v7i8.1984.

Baptista, M. G. F. M. (2013). Mecanismos de Resistência aos Antibióticos,monografia (Dissertação de Mestrado) Curso de Mestrado Integrado em Ciências Farmacêuticas, Universidade Lusófona de Humanidades e Tecnologia, Lisboa. 42. 
Braz., H.., et al. (2020). Estudo in silico da azitromicina, cloroquina e hidroxicloroquina e seus potenciais mecanismos de ação contra a infecção por SARSCoV-2.7(6), 56547-56556. 10.34117/bjdv7n6-18

Blair, J. M. et, al. (2017). Molecular Mechanisms of Antibiotic Resistance. Nature. 13(2), 42- 51. 10.18468/estcien. $2017 \mathrm{v} 7 \mathrm{n} 2 . \mathrm{p45-57.}$

Bosseboeuf, E., Aubry, M., Nhan, T., Pina, J. J., Rolain, J. M., Raoul, T. D. et al. (2018).Azithromycin Inhibits the Replication of Zika Virus. J Antivir Antiretrovir. 10(6) 6-11. 10.4172/1948-5964.1000173.

Colson, P., et, al. Chloroquine and hydroxychloroquine as available weapons to fight Covid-19. Int J Antimicrob Agents. 55(4),105-932.

Costa., Anderson Luiz., Silva Junior., Antonio Carlos Souza. (2016) Resistência bacteriana aos antibióticos e Saúde Pública: uma breve revisão de literatura. Estação Científica (UNIFAP), Macapá. 7(2),45-57.

Calderón, J. L. M., Márquez, F. C. L., \& Flores. (2018). PR.Azitromicina como tratamento contra Chlamydia trachomatis?Centro de Pesquisa Biomédica Mexico. 154 (6), 689-69.

Davidson, R.J. (2019) In vitro activity and pharmacodynamic/pharmacokinetic parameters of clarithromycin and azithromycin: why they matter in the treatment of respiratory tract infections. Infect Drug Resist. 12:585.

Ferracini, F. T., Filho, W. M. B., \& Almeida, S.M. (2014) Atenção à Prescrição Médica, Atheneu.P.53

Fuchs, F. D.; \& Wannmacher, L. (2010). Farmacologia Clínica: fundamentos da terapêutica racional. (4a ed.), Guanabara Koogan.P 55.

Fantini, J., Chahinian, H., Yahi, N. (2020) .Synergistic antiviral effect of hydroxychloroquine and azithromycin in combination against SARS-CoV-2: what molecular dynamics studies of virus-host interactions reveal. International Journal of Antimicrobial Agents. 7(6), 56547-56556. 10.34117/bjdv7n6-18

Guimarães, D. O., Momesso, L. S., Pupo, M. T. (2010). Antibióticos: Importância Terapêutica e Perspectivas para a Descoberta de Novos Agentes. Química Nova. 33(30), 667- 679. 10.18468/estcien. 2017v7n2.p45-57.

Gautret, et al. (2020) Hydroxychloroquine and azithromycin as a treatment of Covid19: results of an open-label non-randomized clinical trial. Ed.1, P.105 949.

Holmes, A. H., Moore, L. S., Sundsfjord, A., Steinbakk, M., Regmi, S., Karkey, A., et, al. (2016). Understanding the mechanisms and drivers of antimicrobial resistance. Lancet. 387(10014), 176-87.

Iriarte, D. F. (2020) Resistência bacteriana aosmacrolídeos: um olhar sobre a azitromicina.monografia, SãoCartos:Universidade Federal de São Carlos.7(8),1984. doi.org/10.51891/rease. v7i8.1984.

Júnior, A. M. (2019). Multirresistência a antibióticos em hospitais. ScireSalutis. 9(2), 1-8.

Kelleni, M. (2020). Nitazoxanide/Azithromycin combination for Covid-19: A suggested new protocol for Covid-19 early management. Pharmacological Research, 157(2) 104-874.

Michael, J., et al. (2014). Azithromycin: Mechanisms of action and their relevance for clinical applications, Pharmacology \& Therapeutics.143(2),225-245.

Meireles, M. A. O. M. (2008). Uso de Antimicrobianos e Resistência Bacteriana: Aspectos Socioeconômicos e Comportamentais e seu Impacto Clínico e Ecológico. 7(2),47. 10.18468/estcien.

Marquioti, C. M. J., Lanes, L. C., \& Castro, G. F. P. (2015). Uso irracional de antibióticos na infância: contribuição do profi ssional farmacêutico para a promoção da saúde. Rev transformar. [citado em 20 fev. 2016]. 13(3),39-77.

Moreno, K. M. M. (2013). Carbapenêmicos: tipos y mecanismos de resistência bacterianos. Rev Med Costa Rica y Centroamericana. 608(8), 599-605.

Neto, I. F. S., Ricardino, I. E. F., Souza, M. N. C., \& Mendes, R. C., (2020) Alvos moleculares dos Fármacos no tratamento da Covid-19. Cadernos de prospecção - Salvador. 13(5), 1251-1271.

Oliveira, A. C., \& Silva, R. S. (2008). Desafios do Cuidar em Saúde Frente à Resistência Bacteriana: Uma Revisão. Revista Eletrônica de Enfermagem. 1(10), 189-197.

Opa-Oms., Anvisa. (2007). Medidas de prevenção e controle da resistência Microbiana e programa de uso racional de antimicrobianos em serviços de saúde RM controle.

Opal, S. M., \& Pop-Vicas, A. (2015). Molecular mechanisms of antibiotic resistance in bacteria. In: Mandell, Douglas, and Bennett's principles and practice of infectious diseases / [editedby] John E. Bennett, Raphael Dolin, Martin J. Blaser. - Eighth edition. Philadelphia: Elsevier. $234-251$.

Oliveira,R \& Aires ,T.(2016). Resistência aos antibacterianos. Artigo de revisão Gazeta Médica. 3(2), 14-21.

Pereira, A. S. et al. (2018). Metodologia da pesquisa científica. Santa Maria: UAB/NTE/UFSM.9(9). http://dx.doi.org/10.33448/rsd-v9i9.7245

Pani, A., Lauriola, M., Romandini, A., \& Scaglione, F. (2020). Macrolídeos e infecções virais: enfoque na azitromicina na patologia de Covid-19., Jornal internacional de agentes antimicrobianos.56(2), 1-18.

Rang, H. P., \& Dale, M. M. (2016). Editora Elsevier, 8aedição, 2016. Farmacologia Clínica. Fuchs, F.D.; Wannmacher, L. Editora Guanabara Koogan.4ed, P55.

Uzunian, A. (2020). Coronavirus SARS-CoV-2 and Covid-19. Jornal Brasileiro de Patologia e Medicina Laboratorial, 56(4).

Vieira, P. N, \& Vieira, S. L. V. (2017). Uso irracional e resistência a antibióticos em hospitais. Arquivos de ciências e da saúde da UNIPAR. $21(3), 209-212$. 
Research, Society and Development, v. 11, n. 1, e31611125035, 2022

(CC BY 4.0) | ISSN 2525-3409 | DOI: http://dx.doi.org/10.33448/rsd-v11i1.25035

Wong, A. (2020). Covid-19 e toxidade de tratamentos potenciais: panaceia ou veneno. EMA Medicina de Emergência Australasia. 32(1), 697-699.

Wang, X. et, al. (2020). Nosocomial outbreak of Covid-19 pneumonia in Wuhan, China. European Respiratory Journal. 55(60).

Ye, Q., Wang, B., \& Mao, J. (2020). The pathogenesis and treatment of theCytokineStorm'in Covid-19. Journal of infection, 80(6), 607-13. 